\title{
Evaluation of Irvingia (I. gabonensis and I. wombulu .Bail) Trade; a major Non-Timber Forest Product in the Ejagham Forest Reserve of South West Cameroon. ${ }^{1}$ Nkwatoh A. F., ${ }^{2}$ Labode P. , ${ }^{3}$ Iyassa S.M. and ${ }^{4}$ Nkwatoh F.W.
}

\begin{abstract}
The Study was carried out between 2002-2008 in the Ejagham Forest Reserve (EFR) of South West Cameroon with the objective of examining the production and marketing of Irvingia species and its economic contributions to National and International Economies of Central and West Africa.

Questionnaires and a selection of PRA tools were used to source information from collectors/gatherers, on occurrence, marketing and market channels for Irvingia species in the study area. Two varieties of Irvingia (I. gabonensis and I. wombulu) were identified to be sourced and processed for the market from the study area. Collection/gathering and processing techniques for Irvingia were characterized by the use of crude tools. Market prices were found to be determined by a few buyers who acted as cartel. ANOVA and t-test analysis showed significant differences in product quantities within and between zones and the seasons at $p<0.05$ level. A total of 1,084,924.1 metric tones of Irvingia was produced and traded between 2002 and 2008, valued at about 2,364,385,162 F (CFA) equivalent to US\$ 4,728,770.34 Internally Generated Revenue (IGR) to the Economies of Cameroon, Central and West Africa.

Key words: Collection/gathering, Marketing, Irvingia, NTFPs.
\end{abstract}

\section{Introduction}

Torests, apart from timber, contain
many useful goods and services of subsistence and commercial value called NonTimber Forest Products (NTFPs), which sustain rural people and rural economies. Adeyuju (1975), Ndouye et al. (1998), and Falconer (1990, 1992) define NTFPs as all forest goods and services, excluding commercial timber. In this context, NTFPs include such diverse products as animal products, leaves, local building materials, edible fungi, medicinal plants, forest foods, sponges, chewing sticks, fibres, gums and rattan canes, among others. These products constitute rural industrial raw materials for cottage industries, cultural symbols, ritual artifacts and traditional medicine (Duncan and Mbenkum, 1989, FAO, 1988, Nkwatoh, 2000). Despite their huge contribution, to humankind, the sector has been subjected to misuse and taken for granted for a long time. Paddock and De Jong, 1995; and Ndouye et al. 1998 put it that, this neglect has been due to lack of appropriate information on their occurrences and prevalence, as well as the growing socio-economic and cultural potentials of these products in the developing and the developed economies of the world.

In the Humid Lowlands of Central and West Africa (HULCWA), there are many of these products in used and their occurrence and prevalence varies among component ecological sub-zones and habitant types. In the past three decades, these NTFPs have attracted greater attention of scientist in the sub-region.
Prominent scientists have carried out research on the prevalence, phonology, socio-economics, genetics and domestication of many of these species. Among these are studies by Okafor $(1981,1986)$ who focused on edible indigenous fruit plants and their importance in rural economy of Nigeria. Egunjobi and Rawal (1973) studied the un-exploited plant resources of Nigeria. Agbor (1986) and Ladipo (1995), worked on the collection and conservation of the genetic resources of Irvingia gabonensis in West and Central Africa. Duncan and Mbenkum (1987), Nkwatoh, (2000), Shiembo et al. (1996), looked at the ethno botany of the Korup National Park and its adjoining Forest Reserves, while Popoola and Oluwalana (1998), Ndonye et al. (1998), Omoluabi (1994), and Nkwatoh (2000) studied the marketing of NTFPs in Cameroon. Despite all these research efforts, one of the major problems facing the NTFPs sector today in Cameroon, the Central and West at large, is the lack of any correlated research that matches biological data with socioeconomic activities (Ndouye, 1995, Nkwatoh, 1995, 2000, 2007). As part of the national drive to source adequate information, on what constitutes the National Stock of NTFPs and its socio-economic situation in Cameroon, Central and West Africa, this study evaluated the production and marketing of Irvingia species; a major NTFP in the Ejagham Forest Reserve and its adjoining forest areas. To achieve this, the study had as its objectives to:

${ }^{1}$ Department of Geology and Environmental Science, Box 63 University of Buea S. W. Region, Cameroon: nkwatohaf@yahoo.com 2Department of Forest Resources management University of Ibadan, Nigeria ${ }^{3}$ Department of Geology and Environmental Science,Box 63 University of Buea S.W.Region, Cameroonail:

${ }^{4}$ G.B.H.S, Bamessing Ndop,Ngoketunjia Division,North West Region, Cameroon. 
(1) Identify the varieties of Irvingia in the study area that are sourced for the market and other end uses. (2) Evaluate the collection/gathering and processing techniques for the identified varieties. (3) Evaluate the marketing and distribution of benefits along the market channel. (4) Assess the Irvingia quantities involved in local and external trade and its contribution to National and International Economies

\section{Materials and Methods \\ Study Area}

The study area (Ejagham Forest Reserve and its adjoining Villages) is located in the South West Region of Cameroon. It extends from latitude $50^{\circ} 10^{\prime}$ to $50^{\circ} 70^{\circ} \mathrm{W}$ and from longitude $80^{\circ} 47^{\prime}$ to $90^{\circ} 11^{\prime} \mathrm{S}$, and shares $95 \mathrm{~km}$ of its western border with the Cross River State of Nigeria, occupying an area of about $640 \mathrm{Km} 2$ (MINIPAT, 2000. SOWEDA, 2000, MINFOF, 2007). The study area has a humid tropical climate, characterized by a single short dry season (November- February) and corresponding long wet season (MarchOctober). The mean annual rainfall for the period of the study (2002 - 2008) was about $1134 \mathrm{~mm}$ with monthly peaks in July and August of every year (Gartland, 1986, Besongabang weather station 2007 ;)

The mean monthly temperature ranged between $24^{\circ} \mathrm{C}$ and $27^{\circ} \mathrm{C}$ in February and January respectively and a maximum of $33.9^{\circ} \mathrm{C}$ in March of every year (Gartland, 1984; Besongabang weather station 2005, 2007)

The area is flat, with an altitude of approximately $50 \mathrm{~m}$ above sea level. The area is drained by Rivers Munaya in the North, and centrally by River Awa and a number of small streams.

The vegetation of the area is of a closed-canopy, moist evergreen lowland rain forest of the Guinea-Congolian type (White, 1993).

\section{Methodology}

The study made use of Biological and socio - economic assessment techniques.

Random sampling, some selected Participatory Rural Appraisal (PRA) tools, questionnaires, visual assessments, and key-in formats, were used for the collection of data on the collection/gathering and the marketing of Irvingia in the study area.

The study area was divided in to three zones A, B and C based on accessibility for data collection: ZONE A: This consisted of villages that were accessible by road all year round.
ZONE B: This consisted of villages that were less accessible by road all year round.

ZONE C: This consisted of villages that were none accessible by road all year round.

From each of these zones, six villages were selected randomly. A total of 18 out of 28 villages were selected for the study. In each of the 18 villages, 50 questionnaires were administered giving a total of about 300 questionnaires per zone and 900 questionnaires in all with a sampling intensity of $60.3 \%$. One set of Questionnaire divided into four sections A, B, C and D. was administered to Village Chiefs, Village Traditional Council members, Traders of NTFP, Farmers, Irvingia, collectors/gatherers, hunters, students, pupils, school teachers, Agricultural and Forestry Extension Staff and the various Forest Users Groups.

In order to complement the socioeconomic data collected on the identified Irvingia species in use, the Line Transects Technique was employed. In each of the selected villages in the three zones, three $1 \mathrm{~km}$ transects were established perpendicular to the main access road or foot path of the area. Along each transect, within the range of $20 \mathrm{~m}$ on both sides, a 100\% inventory of all the Irvingia species sited, were identified and enumerated.

Descriptive statistics such a frequency distribution and tabular analysis of the respondent's dispositions and attitudes was employed for analysis.Non-parametric statistics (ANOVA, T-test) were used for the establishment of significant differences. Trade margin analysis was employed to determine the distribution of benefits along the Irvingia marketing chain.

\section{Result}

\section{Occurrence of Irvingia species in the study area.}

Two varieties occur in the study area; Irvingia gabonensis and I. Wombulu belonging to the family Irvingiaceae. The former produces fruits in the wet season (May-October) with a peak production in July and August. The latter species produces fruits in the dry season (December-April) with a peak production period in February and March. The fruits of Irvingia gabonensis have a fleshy mesocarp with a sweet taste when eaten by animals and human beings; hence it is locally called the sweet bush mango. On the other hand, the fruits and mesocarps of Irvingia wombulu are fleshy, with a bitter taste, hardly eaten by animals and 
humans, and locally called the bitter bush mango.

\section{Main Sources of Irvingia species in the study area. \\ Two varieties of Irvingia that occur in the study area are sourced from a wide range of ecotypes as summarized in table 1. \\ Processing Techniques for I. gabonensis and I. wombulu}

When Irvingia fruits get ripe, they fall from the tree branches to the ground where they are gathered. The gathered fruits are cracked open using a sharp knife following a natural line on the fruit. The tip of a knife or the flattened tip of a five-inch nail is used to remove the cotyledon (kernel) for drying. Drying takes 2 to 5 days depending on the intensity of the heat from the sun during the dry periods. This process gives rise to clean and attractive kernels which attract a better market price.

Secondly, if the fruits fall and are not gathered but left until their mescocarp starts' rotting away before they are gathered, the rotten fleshy mesocarp is squeezed away leaving behind the seed. Cracking may be done immediately or after smoking the seeds over fire on platforms made with bamboos or sticks about $1.5 \mathrm{~m}$ above the fire place in the kitchen. The Irvingia here acquired is not as clean and attractive as the one got from the process described earlier.

This yields a lower grade of Irvingia kernels. This fall in quality is attributed to the germination process already initiated in the seed before they are gathered, resulting in the conversion of some food reserves to support the germination process.

\section{Storage of Irvingia kernels:}

Irvingia is stored in four ways. Three of these ways are as seeds and the other as kernels. (1) When the Irvingia fruits are gathered and left to get rotten, the fleshy mesocarp are squeezed to release the seeds. These seeds are then sun-dried for a while to drain. After draining, they are gathered and put in a synthetic bag and hung over a fire place for storage. When needed, the seeds are removed, cracked and sun dried for about one or two days and marketed. (2) In the second stage, the squeezed seeds are first sun-dried for it to drain and later spread on a platform built out of bamboos over a fire place in the kitchen. They are kept in this condition until when needed. When ever they are needed the seeds are removed, cracked and sun-dried for a few hours before use is made of. (3) In the third stage, after gathering the fallen fruits, they are kept either under the tree or by the house for the mesocarp to rot. This process produces a slimy substance, which acts as a gum that helps to hold the seeds as they are smeared to the outside walls of local mud houses. The seeds are left on the walls to dry in storage before they are removed and cracked as the need arises for marketing or local consumption. (4) In the fourth stage, cracked kernels are dried to the acceptable market level and if marketing is not done immediately, they are put in cement bags, tied firmly and put on a platform over a fire place for storage. During such a storage period, these bags are removed from time to time and the kernels sun dried to reduce humidity and hence check molding.

\section{Grading of Irvingia kernels}

From the processing and storage methods discussed above, there emerge four grades of Irvingia. Grade one, which is the best grade, is obtained after cracking fresh fruits with the fleshy mesocarp still intact. Grade two which is the second best grade is obtained when cracking is done about a week after the rotting away of the fleshy mesocarp. This is because before cracking, the cotyledon must not have started germination. When the seeds are left within the rotten mesocarp for more than 3 weeks before cracking is done, the third grade of mango is obtained. This is because of the initiation of the germination process, which converts some of the stored food of the seed into energy to aid germination, thereby reducing the food value of the cotyledon (kernel) which is the principal market factor. The fourth grade emerges when cracked

Irvingia is dried directly using the direct heat from the fire. The heat causes the oily ingredient in the kernels to melt out which in due course stains the face of the kernels. This results in a dark-brown oily unattractive product. These grades can however change in the process of storage. If grade 1 is not properly dried and stored, the white clean and attractive colour will gradually change to milky white with multiple dark spots (mould).

\section{Problems associated with Irvingia processing}

Far distances covered by collectors to collection sites are a major. The squeezing of the rotten mesocarp is nasty and the accompanying fluids stain the palms and make them rough. Cracking of the fruits with the mesocarp still in tact to get the first grade, often leads to cases of 
finger trimming and infliction of wounds on the fingers.

\section{USES}

Used as a soup thickener, condiments in Central and West Africa and can conveniently replace groundnuts and okoro when prices of these items are high.

\section{Marketing of Irvingia gabonensis and Wombulu}

Irvingia (Kernels) are processed in the study area by village producers. Processed stock is sold to buyers (Nigerians) who move from door to door and from village to village in search of the Irvingia (Kernels). The product is measured and sold in 15litre buckets and other containers that are direct fractions of the bucket, such as $1 / 2$ bucket and $1 / 4$ bucket. The two varieties of Irvingia found in the study area are season specific. Irvingia Wombulu occurs in the dry season while Irvingia gabonensis occurs in the Wet season.

The price of a bucket of Irvingia in any of these villages varies with the distance of the village from the single road net-work into the inner villages of the study area. The cost price of a bucket of Irvingia at the start of the production season is usually high (Zone $\mathrm{A}=18.000 \mathrm{FCFA}$, $\mathrm{B}=15.000 \mathrm{FCFA}$ and $\mathrm{C}=10.000 \mathrm{FCFA}$ ) and as the production season progresses to the peak of production, the price drops (Zone $\mathrm{A}=12.000 \mathrm{FCFA}, \quad \mathrm{B}=10.000 \mathrm{FCFA}$ and $\mathrm{C}=5.000 \mathrm{FCFA}$ ). Towards the end of the production season, the price increases again to about (Zone $\mathrm{A}=22.000 \mathrm{FCFA}, \mathrm{B}=18.000 \mathrm{FCFA}$ and $\mathrm{C}=12.000 \mathrm{FCFA}$ ) for a 15 Litre bucket.

\section{Irvingia trade cycle and channel}

Buyers of Irvingia in the villages after buying, transport their stock by head load to the assembly centers. At these centers, the stock is assembled and re-bagged in bigger bags. From the assembly centers, the stock is transported to the main market centre on Sundays in preparation for the Monday Market at Ikom in Cross River State Nigeria. At Ikom as fig. 1 puts it, the buyers (now suppliers) supply their stock to the wholesalers who buy in bulk. The wholesalers in Ikom belong to an Irvingia market Union. This union enjoys the monopoly of being the only organisation on the Ikom market, charged with the responsibility of facilitating the transfer of Irvingia stocks from the hands of suppliers into the hands of the wholesalers.

After a successful transfer of stock from the hands of suppliers to the wholesalers, the Irvingia suppliers make a return into the study area villages to buy more stocks, and the cycle continues. This cycle is usually completed within a week and the cycle is repeated until the Irvingia season is over.

The arrows in fig 1 show the unidirectional movement of Irvingia from the forest to the retailers. The double arrows for the retailers indicate that they can also buy Irvingia when in short supply, from their fellow retailers. Bulk buyers in the course of distribution distribute to more than one retailer.

\section{Market margin for Irvingia}

Total benefits observed for a producer of Irvingia in a month varied from zone A to Zone $\mathrm{C}$ as follows: Zone $\mathrm{A}=4675 \mathrm{FCFA}$ (US\$ 9.35), Zone $\mathrm{B}=2350 \mathrm{FCFA}$ (US\$ 4.7) and $\mathrm{C}=$ 300fs CFA (US\$ -6.00). From the above variations, it was clear that, producers in Zone $\mathrm{A}$ derived more benefits while producers of Zone $\mathrm{C}$ produced and sold at a deficit This is further demonstrated by the analysis from returns to investment of the producers presented as follows:- $48.7 \%$ for zone A, $24.5 \%$ for Zone B and-3.1\% Zone C. The second group of participants-the buyers (suppliers) had total cost at destination of 19275fs CFA US\$(38.55) for Zone A, 17450fs CFA (US\$ 34.9) for Zone B and 15300fs CFA (US\$30.6) for Zone C. After the sales of their produce at the Ikom market, they had a corresponding market margin of 8725 FRS CFA for Zone A, 10550 fs CFA for Zone B and 12700 fs CFA for Zone C. The analysis showed that buyers who bought their produce from zone $\mathrm{C}$ had the highest margin while buyer from Zone A had the lowest. Returns to investments further highlights this claims as follows. Zone A $45.3 \%$, Zone B $60.5 \%$ and Zone C $83 \%$. 


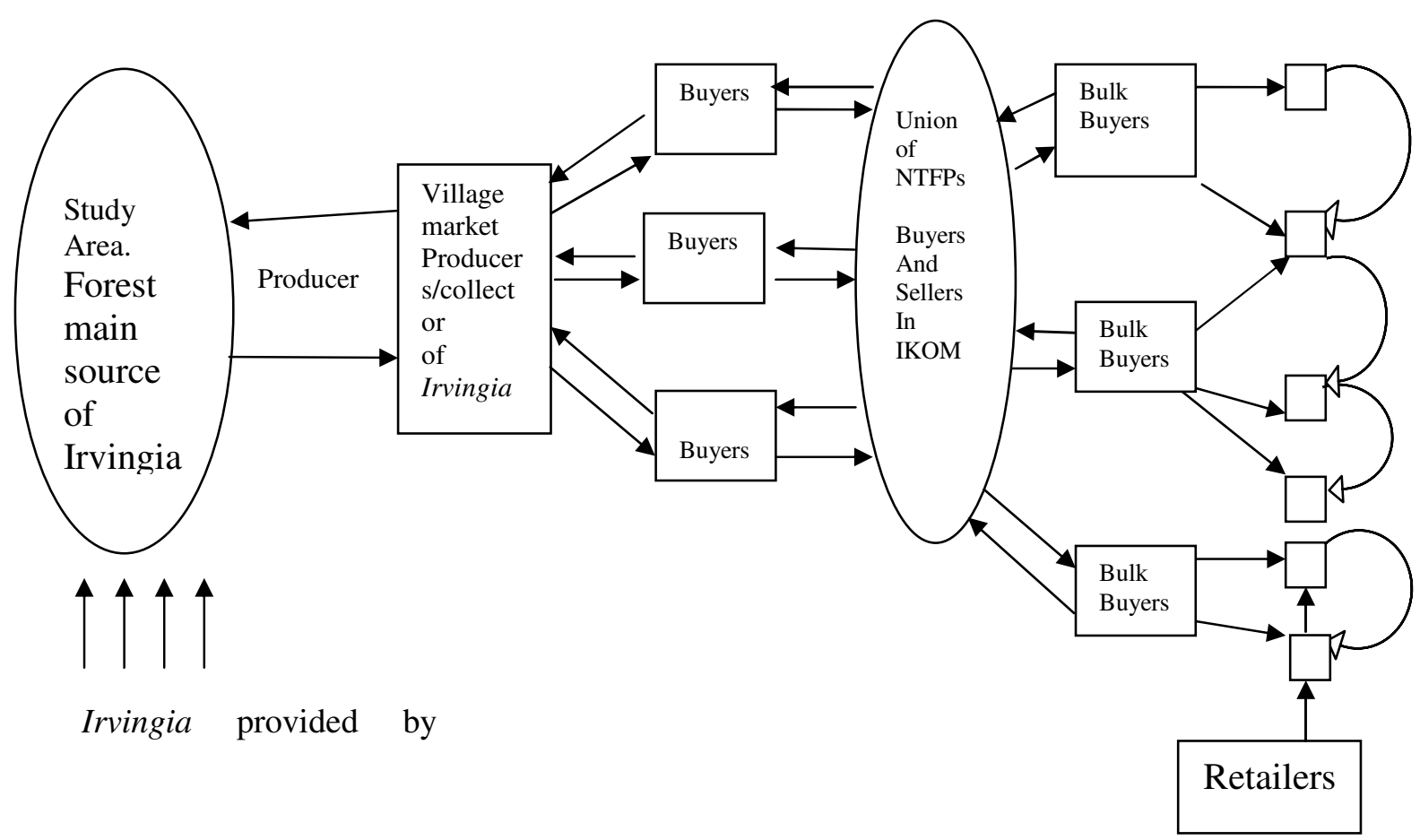

Fig. 1 Schematic Diagram for Irvingia Market Channel

\section{Quantities of Irvingia kernels traded between 2002 and 2008.}

The quantities of Irvingia (Kernel) traded in the study area between 2002 to 2008 varied significantly from zone $\mathrm{A}$ to zone $\mathrm{C}$ at the $\mathrm{P}=0.05$ level of significance. T-test analysis which compared the means of the two products with respect to the two seasons, showed that both species of Irvingia showed significant variation in quantity harvested and sold in the two seasons at the $\mathrm{P}=0.05$ level of significance. As table 3 puts it, the volume of Irvingia gabonensis gathered and sold from the study area has been on the decline while that of Irvingia wombulu has been on the increase from 2002 to 2008. The quantity of Irvingia Kernels involved in the Irvingia trade in the study area and across the Nigerian boarder from 2002 2008 , was about $1,084,924$ tones contributing a total of about 2,364,385,182FCFA equivalent to USD\$.4.728770.4 to the economies of Cameroon, Central and West Africa.

\section{Conclusion}

I. gabonensis is highly abundant in the study area than I. wombulu. This is not unconnected to the fact that $I$. gabonensis fruits as a result of its being eaten by humans and animals and its season of occurrence, helps in rapid seed dispersal. On the other hand, I. wombulu with bitter fruits that are selectively eaten by a few species of animals and its season of occurrence (dry season), are poorly dispersed with low seed germination and eventual stabilization as a plant. This explains the reason why they are more abundant on fallow and farm lands than any other ecotype as a result of the additional efforts the farmers make to aid their effective stabilization. The collection/gathering of Irvingia products in the study area as Nkwatoh, (1995, 2000, 2007), Besong, (1997), Adekunle, (1971), puts it, was observed to be ecosystem destructive, as almost all the seeds that fall to the ground are gathered and processed for the market, short chancing the present stock from multiplying.

Producers of Irvingia in general in the study area had a lower margin while buyers of Irvingia enjoyed a higher margin of benefits along the Irvingia trade chain. This was attributed to a number of issues: The first being the lack of improved processing methods for Irvingia that could add value and increase product selling prices, (Vabi, 1995). The second issue was the lack of Market information, which made it difficult for the producers to project quantity demanded, which is a function of market price setting (Ndouye, 1998).

The third issue was the lack of storage facilities at the village level, which made it difficult for the producers to store the products 
beyond the peak production seasons (Falconer, 1990, FAO, 2005).

On the other hand, variation in margins was also observed for producers and buyers with respect to zones, where producers of zone $\mathrm{C}$ emerged with the lowest margins, and buyers from zone $\mathrm{C}$, emerging with the highest. This was attributed to the in accessible nature of zone (C) which made very few buyers to reach. The few buyers, who manage to reach the zone, offered very low prices and acted as cartels. As they sold on the same market with buyers of zones $\mathrm{A}$ and $\mathrm{B}$, they ended up getting more than buyers from accessible zones that bought at higher prices than them. Producers of zone $\mathrm{C}$ emerged with deficits because of the low prices that were paid for their products, irrespective of the same labour cost that was incurred like

\section{References}

Adekunle, A. O. (1971). The non-Timber Forest resources of the high forest area of Nigeria. Nigerian Journal of Forestry 1 (1): 1216.

Adeyoju, S. K. (1975). Forestry and the Nigerian Economy 308pp.

Egunjobi, J.K. and Rawal, K.M (1993): Proceedings of the Conference on Environmental Resources Management of Nigeria. University of Ife, Nigeria, 31-37pp.

Agbor, L. O. N. (1986). Economic assessment of Irvingia gabonensis in Cross River State Nigeria. MSc. Thesis, Department of Forest Resources Management, University of Ibadan.

Besongabang Weather Station, 2005, 2007. Monthly weather report: for the Provincial Delegation of Weather Observation and Monitoring, South West Province Cameroon. 11-17pp.

Besong, J. B. (1997). Best options for securing the future of the African Rain Forest. Proceedings of the African Rainforest and conservation of Biodiversity conference. Limbe Bolanical Garden Cameroon. 170pp (3943).

Duncan, W. T; James, M. T, Wendy, A. B. and Fonki, T. M. (1989) Korup ethnobotanical survey. Final report to the World Wide Fund for Nature.

Duncan, W. T. and Mbenkum, F. T. (1987) Medicinal and food plants from Cameroon's Forest Development and Conservation. (UNDP/FAO Forest Sector Review of Cameroon, Inter Agency joint mission to Cameroon). producers of zone A and B (Nkwatoh, 2000, Omoluabi, 1994)

The Irvingia sector in the Ejagham Forest Reserve has been playing a vital role in the growth and development of not only the local economy, but also the national as well as the international economies. In these communities, the sale of Irvingia kernels, help in the stabilization of local incomes as well as providing seasonal employments to both men and women for a greater part of the year. Besong 1997, Ndouye, 1998, in a related study in the Cross River State of Nigeria and the forest zones of Cameroon, confirmed that about 60 $90 \%$ of rural populations of these areas are fully employed by the Agricultural and the forestry sectors of the economy.

Falconer, J. (1990). "Non-Timber Products in Ghana's Forest zones: Issues for forest conservation". In Conservation of West and central African Rainforest, edited by Kavin Cleaver, Moham. M, Mary, O. Nocolas. E, Axel, P. Francis, W. World Bank environmental paper No. 1.

Falconer, J. (1992). Non-Timber Forest Products in Southern Ghana. A summary Report. ODA Forestry series No. 2 Natural Resources Institute Chatam.

Falconer, J. (1995). The major significance of minor forest products. The local use and values of forest in the West African Humid Forest zones. Community Forestry Note. N0. 6. Rome FAA.

FAO, 1995: Forest Resources assessment 1990.

Survey of Tropical Forest cover and study of change processes FAO Forestry paper No. 130 Rome.

FAO, 1998. Non-Wood Forest Products of Central Africa: Current Research Issues and Prospective for Conservation and Development. Edited by Terry C.H Sunderland, Laurie E. Clark and Paul Vantomme.288p.

Gartland, J. S. (1986). The biological and historical importance of Korup forest. In J. S. Gartland and H. Macleod (eds), Workshop on Korup National Park, (pp 28-35). Mundemba, Cameroon WWF/IUCN Project 3206.

Ladipo, D.O. (1995): Collection and Conservation of the Genetic Resources of Irvingia gabonensis in West and Central Africa. Unpublished Report. ICRAFT. Nairobi, Kenya.26pp. 
MINIPAT 2000. National Population and Housing Census of Cameroon Report, 674pp. Popoola, L. and Oluwalana, S. A. (1998). Marketing of NTFPs in Nigeria. Paper presented at the colloquim on Biodiversity (Rainforest-Ecosystem of Nigeria). Organised by FEPA-UNAAB.

Ndouye, O and Nicodeme, T (1994). Utilization and marketing of Irvingia gabonensis products in the Humid forest zones of Cameroon,. Rocker filler foundation post doctoral fellow at IITA station, Yaoundé Cameroon.

Ndouye, O. (1995) "Commercialization and diversification opportunities for farmers in the humid forest zones of Cameroon. The case of INon-Timber forest Product consultancy report for an alternative to slash and Burn (ASB) Project.

Ndouye, O., Riiz, M, and Ayebe, A (1997). The markets of Non-Timber Forest Products in the Humid zones of Cameroon. Rural Development forestry Network, paper 22c, ODI, London.

Ndouye, O, Reiz, M. and Ayebe A. (1998).

NTFPs markets and potential sources for forest Resource degradation, in central Africa. The role of ?research for a balance between welfare improvement and forest conservation. Paper presented at the international export workshop on NTFPs for central Africa. Limbe Botanic Garden Cameroon.

Nkwatoh, A. F. (1995). Production and marketing of NTFPs in the Ejagham Forest Reserve and cross border trade in NTFPs with Nigeria. A Report prepared for GTZ Korup Project Cameroon.

Nkwatoh, A. F. (2000). Evaluation of Trade in Non-Timber Forest Products in the Ejagham Forest Reserve of South West Cameroon. Ph.D. Thesis University of Ibadan (Un pub.) 167 pp.

Okafor, J. C. (1981) Wood plants of nutritional importance in traditional farming system of Nigeria's Humid tropics. Ph.d thesis. Ibadan Nigeria.

Okafor, J. C. (1986) Towards diversification and improvement of alley- farming system in Nigeria's humid tropics. Paper, presented at the 1986 Annual Conference of the Forestry Association of Nigeria.

\section{Acknowledgement}

I wish to extend my gratitude to Mr Nkwatoh Francis and Family and the entire staff of Korup Project Eyumojock for their support for the successful conduct of this work.
(1988) Trees for food and fodder in the Savanna areas of Nigeria. International Tree Club Journal Vol. 1 22-24.

Omoluabi; A. C. (1994). Trade in Timber and Non-Timber Forest Products in Cross River State of Nigeria. A report prepared for the Cross River Forestry Project Calabar, Cross River State Nigeria.

-(1994). Market margins in Non-Timber Forest Products trade in Cross River State of Nigeria. Working paper No. 12 prepared for the Cross River Forestry Project Calabar Cross River State Nigeria.

Paddock, C, and De Jong; W. (1995). Production and profits in agro forestry: an example from the Peruvian Amazon. In J. G. Browder, ed. Fragile lands of Latin America. Strategies for sustainable development. P 102113, Boulder, Colorado. USA.

Popoola, L. and Oluwalana, S.A. 1998. Marketing of NTFPs in Nigeria. Paper presented at the colloquium on Biodiversity (RainforestEcosystem of Nigeria). Organised by FEPAUNAAB.

Shiembo, P. N. (1994). The domestication of Non-Timber Forest Product in Cameroon. Ph.D Thesis presented to the Department of Forestry, University of Edinburgh, U.K.

Shiembo, P. N. Newton, A. C. and Leakey, R. R. $\mathrm{B}(1996)$ Vegetative propagation of Gnetum africanum Welw., a leafy vegetable from West Africa, Journal of Horticultural Sciences 71(1): 149-155.

Vabi, M. B. (1995). Determining Economic opportunity for inhabitants of some villages in the support zone of the Korup National Park Report prepared for GTZ Korup Project with particular reference to NTFPs and Gender $56 \mathrm{pp}$. Vabi, M.B. 1995. Community knowledge and traditional uses of trees in some village communities of Cameroon and the Central African Republic. Paper prepared for the Regional symposium on Agro-forestry Research and Development in the Lowlands of West and Central Africa.

SOWEDA. 1999/2000 Annual Progress Report. July $\quad 1999 \quad$ - $\quad$ June 2000. 
Table 1. Main Sources of Irvingia gabonensis and wombulu

\begin{tabular}{|c|c|c|}
\hline Ecosystem types & Irvingia species & Degree of abundance. \\
\hline 1. Primary Forest & $\begin{array}{l}\text { I. gabonensis } \\
\text { I. wombulu }\end{array}$ & $\begin{array}{l}++++ \\
++\end{array}$ \\
\hline 2. Secondary Forest & $\begin{array}{l}\text { I. gabonensis } \\
\text { I. wombulu }\end{array}$ & $\begin{array}{l}++++ \\
+++\end{array}$ \\
\hline 3. Fallow land & $\begin{array}{l}\text { I. gabonensis } \\
\text { I. wombulu }\end{array}$ & $\begin{array}{l}++++ \\
++++\end{array}$ \\
\hline 4. Farm Lands & $\begin{array}{l}\text { I. gabonensis } \\
\text { I. wombulu }\end{array}$ & $\begin{array}{l}++++ \\
++++\end{array}$ \\
\hline
\end{tabular}

Source: Field survey, 2002-2008.

+ indicates less abundant, ++ Indicates abundant,

+++ Very abundant, ++++ Highly abundant,.

Table: 2 Grading of Irvingia according to processing and storage method

\begin{tabular}{|l|l|l|}
\hline Grade & Colour & Observation \\
\hline \hline 1. & Whitish & Very clean and attractive \\
\hline 2. & Brownish & Slightly attractive \\
\hline 3. & Stained brown & Poorly attractive \\
\hline 4. & Dark brown & Oily and not attractive \\
\hline
\end{tabular}

Source: Field Survey: 2002-2008

Table: 3 Total Quantities of Irvingia kernels obtained from Ejagham Forest Reserve in both seasons (Dry and Wet) between 2002-2008 (tones)

\begin{tabular}{|l||l|l|}
\hline Years/Products & I. gabonensis & I. wombulu \\
\hline 2002 & 123348.8 & 56207.4 \\
2003 & 118516.5 & 59599.7 \\
2004 & 114038.3 & 57725.0 \\
2005 & 112276.4 & 68062.6 \\
2006 & 109675.7 & 69560.8 \\
2007 & 90264.7 & 71001.5 \\
2008 & 90003.4 & 76943.3 \\
\hline Total & 758123.8 & 326800.3 \\
\hline
\end{tabular}

Source: Field survey, 2002-2008 